\title{
Innovative development of Russian industry: regional problems and opportunities for their solution
}

\author{
Valentina N. Parakhina \\ Head of the management department \\ The North-Caucasus Federal University (NCFU) \\ Stavropol, Russia \\ vparakhina@ncfu.ru
}

\author{
Olga A. Boris \\ Professor of the management department \\ The North-Caucasus Federal University (NCFU) \\ Stavropol, Russia \\ oboris@ncfu.ru
}

\author{
Pavel N. Timoshenko \\ Dean of Humanitarian Faculty \\ Nevinnomyssky State Humanitarian-Technical Institute (NSHTI) \\ Nevinnomyssk, Russia \\ timpol@bk.ru
}

\begin{abstract}
The paper studies the dynamics of the manufacturing sector in the Russian Federation, North Caucasus Federal District (NCFD) and Stavropol territory. It shows that it varies considerably by type of economic activity. It was found that the decline in output of mechanical engineering was the dominant factor that affected the level of business activity of adjacent industries. The estimation of the change of the index of business confidence organizations. In the structure of the manufacturing sector in economic activity of Stavropol region, the highest share of food production and chemical production was revealed. This chemical industry is developing based on innovation, and for the production of food, it is characterized by low investment activity, high depreciation of fixed assets, obsolete technology and lack of processing facilities in major vegetable and meat products. Their development is possible on the basis of an extensive system of interbranch relations by forming integrated structures, including a central unit ("core") - one of the leading manufacturing industries in the region. Solution of infrastructure and technology problems based on the integrative approach significantly strengthens the competitive position of local producers.
\end{abstract}

Keywords - Manufacturing, North Caucasus Federal District, innovative development, industry structure, the business activity, index of business confidence

\section{INTRODUCTION}

The necessity of structural transformation of domestic industry, the growth of its competitive positions and modification of facilities and equipment of institutions as well as outlet development of manufacturing activities coincided with the crisis in native economics, which was the original cause of the global crisis and financial restrictive trade measures, adopted by major world powers against Russia.

\section{PROBLEM IN THE RUSSIAN ECONOMY}

There is renewal of demand within global and, in particular, internal market of energy recourses; the growth of mining operations stimulates manufacturing development.

The rise of industrial production in Russia in 2013 was $109.0 \%$ in relation to 2010 , including the extractive and processing industries, which were $103.4 \%$ and $115.3 \%$ respectively.

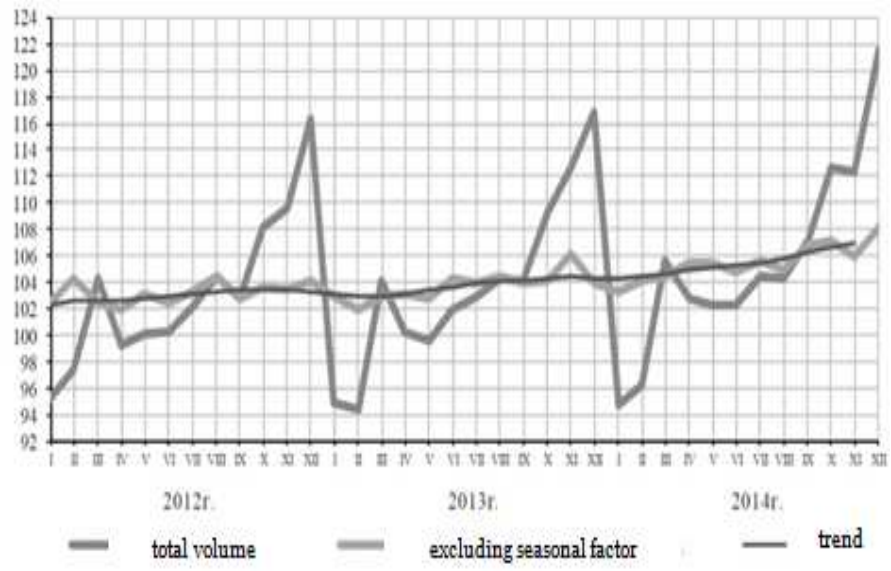

Fig.1. Growth of industrial output in the Russian Federation, indexes in percent are taken as an average monthly indicator, $2011[1,2]$.

Dynamics of manufacturing activity in the Russian Federation demonstrates absolutely sustainable growth during three years, excepting seasonable slumps at the beginning of the year (Fig. 2). 


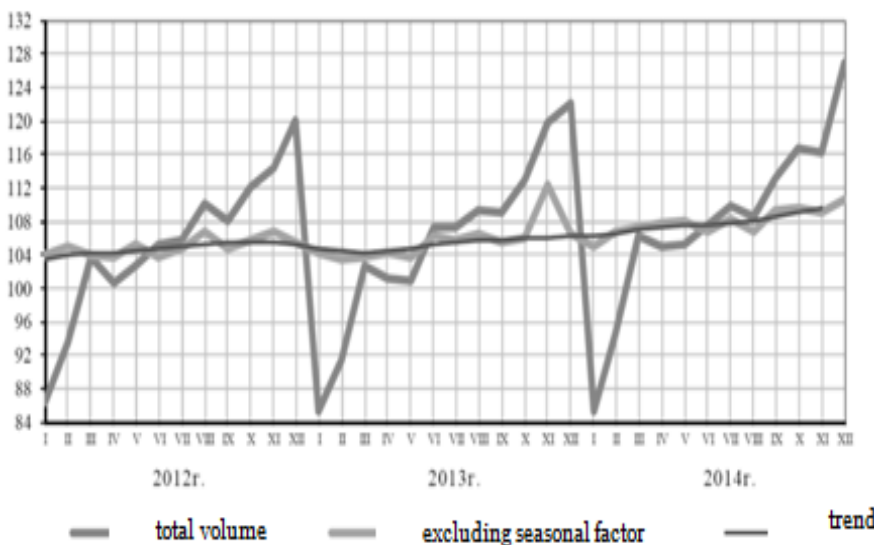

Fig. 2. Dynamics of manufacturing activity in the Russian Federation, indexes in the ratio to average monthly indicator, $2011[1,2]$.

However, the dynamics of manufacturing activity sufficiently varies by types of economic activity; herewith the ratio of production rates and consumer goods impacts most significantly on the growth characteristics, which requires the integration of these production forms to ensure sustainable growth of manufacturing industry.

The analysis shows that in post-crisis period the production volume of food, leather, coke and mineral oil, chemical products, as well as the output of rubber and plastic products, exceeded the production level in the pre-crisis period, while vehicles, machinery and metallurgical products are manufactured at the level below the pre-crisis period indicators [3, 4].

Owing to considerable variations of growth rates in manufacturing activity, a sharp decline of output of machinery goods became the dominant factor that influenced negatively the business activity rate of associated industries in production of structural materials and other types of related products in crisis and post crisis periods $[5,6]$.

At the same time, business activity and confidence in the mining operations sector continue to be above average for the industry Fig. 3).

(a)

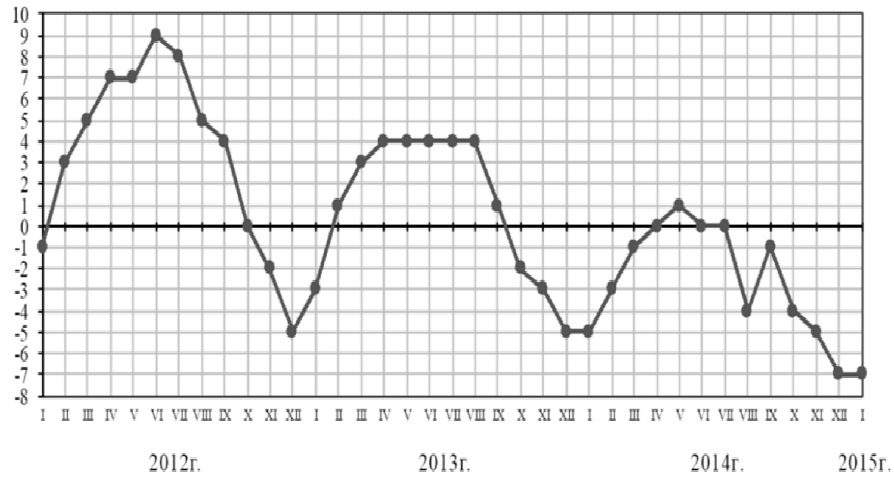

(b)

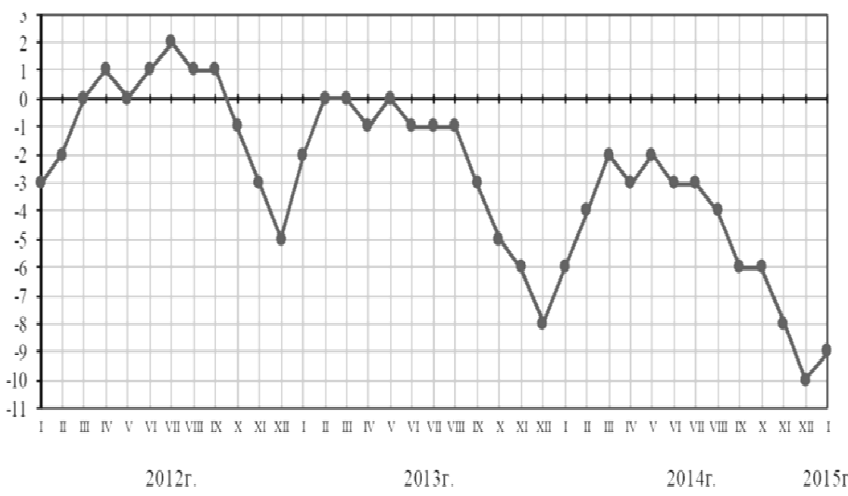

Fig. 3. Business Confidence Index of mining operations (a) and manufacturing activity (b) in percent $[1,2]$.

As charts figure show, in more than half of the observation period (20 out of 36 months, that is, $55.56 \%$ cases), entrepreneurs of mining operations sector evaluate the outlook for the industry positively, while the heads of business entities in manufacturing are rather pessimistic.

Only 10 out of 36 cases, that is $27.78 \%$ cases of the assessment, are positive and in the overwhelming majority (72.22\%), they are negative that certifies about a lack of confidence in the success of activity and desire to invest in development of the industry. Although in January 2015, practically all sub industries of manufacturing activity were unattractive for business community where business confidence index has fallen up to average - (minus) 9 (Fig. 4).

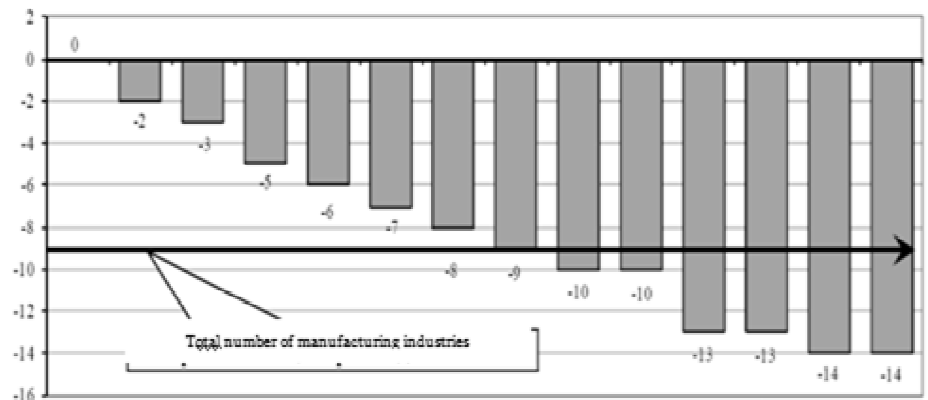

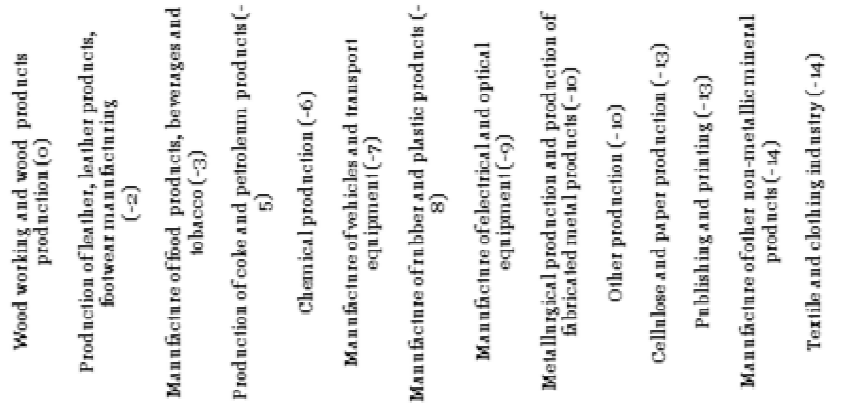

Fig. 4. Business Confidence Index of manufacturing industry institutions (without small enterprises), January 2015 [2].

The decline of development in engineering industry has been revealed in 2013, but was significantly lower than the average level in the manufacturing sectors. Though the 
dynamics of engineering production came to the positive indicators in 2010. In particular, the State automotive industry support, including measures to stimulate demand, has led to the increase of growth of Russian machinery production.

In recent years, import products have provided a significant impact on growth of engineering industry. This is due to the fact that the low competitiveness of a large number of vehicles and machinery in comparison with imported products according to the criteria of "price/quality", as well as a small number of enterprises, producing modern equipment, substantially limits the markets for the products of Russian engineering industry.

The influence of import supplies considerably varies in different sectors of economic activity and marks of goods [7]. The market of investment engineering industry has been connected with an increase in import, which is an important factor in the implementation of investment projects and programs, modernization of enterprises and technological innovations introduction.

The increase of competition of imported goods in such engineering sectors as machine-tool construction, production of vehicles, road-building and agricultural machinery was also noticed [8, 9]. For these enterprises, the low level of investment activity, an accumulated depreciation and out of date technologies are significant. The transfer of activities of foreign firms to the Russian territory became an important perspective direction for the development (industrial installation) $[10,11]$.

An advanced increase of goods production with involved overseas investment changed the terms of competition and stimulated the activity of traditional industries [12,13].

However, these enterprises were the most vulnerable in crisis period, as necessary timely activities are not undertaken for development of output parts at the Russian enterprises. Taking into account the broad system of inter industry connections, both in mechanical engineering and auto industry, a sharp decline of production affected the associated industries, sectors of infrastructure and negative impacted employment of the population $[14,15]$.

\section{THE SPECIFICS OF THE PROBLEMS IN THE REGION'S ECONOMY}

The structure of production in Stavropol region and NCFR is that the share of manufactured goods nearly half as much exceeds the share of agricultural products though the share of agricultural products in the North Caucasus Federal Region is one of the highest among the federal districts of the Russian Federation [7].

In full accordance with ARCEA (All-Russian Classifier of Economic Activities), the industry sector of NCFR includes: mining operations, manufacturing industries, production and allocation of electric energy, gas and water recourses (Table I).
TABLE I. INDUSTRIAL STRUCTURE OF NCFR DISTRICTS, 2013.

\begin{tabular}{|c|c|c|c|c|c|}
\hline & \multirow{2}{*}{$\begin{array}{l}\text { Gross } \\
\text { regional } \\
\text { product, } \\
2012 \text {, } \\
\text { million } \\
\text { rubles }\end{array}$} & \multicolumn{3}{|c|}{$\begin{array}{l}\text { Volume of dispatched goods of } \\
\text { private industry, Economic } \\
\text { activities, million rubles }\end{array}$} & \multirow{2}{*}{$\begin{array}{l}\text { Total } \\
\text { agricult } \\
\text { ure } \\
\text { product } \\
\text { ion, } \\
\text { million } \\
\text { rubles }\end{array}$} \\
\hline & & $\begin{array}{l}\text { Mining } \\
\text { operations }\end{array}$ & $\begin{array}{l}\text { Manufac } \\
\text { turing } \\
\text { activity }\end{array}$ & $\begin{array}{l}\text { Producti } \\
\text { on and } \\
\text { allocatio } \\
n \quad \text { of } \\
\text { electric } \\
\text { energy, } \\
\text { gas and } \\
\text { water } \\
\text { recourses }\end{array}$ & \\
\hline $\begin{array}{l}\text { North- } \\
\text { Caucasian } \\
\text { Federal } \\
\text { Region } \\
\end{array}$ & 1214729 & 20337 & 293914 & 110892 & 299940 \\
\hline $\begin{array}{l}\text { The } \\
\text { Republic of } \\
\text { Dagestan }\end{array}$ & 377975 & 3109 & 30708 & 14077 & 76814 \\
\hline $\begin{array}{l}\text { The } \\
\text { Republic of } \\
\text { Ingushetia }\end{array}$ & 36888 & 1344 & 3191 & 1477 & 4640 \\
\hline $\begin{array}{l}\text { The } \\
\text { Kabarda- } \\
\text { Balkar } \\
\text { Republic }\end{array}$ & 105992 & 175 & 24126 & 7333 & 32699 \\
\hline $\begin{array}{l}\text { The } \\
\text { Karachai- } \\
\text { Cherkes } \\
\text { Republic }\end{array}$ & 59513 & 1942 & 37600 & 6080 & 22430 \\
\hline $\begin{array}{l}\text { The } \\
\text { Republic of } \\
\text { Nothern } \\
\text { Osetiya- } \\
\text { Alaniya }\end{array}$ & 99715 & 433 & 16639 & 7074 & 25877 \\
\hline $\begin{array}{l}\text { The } \\
\text { Chechen } \\
\text { Republic }\end{array}$ & 103677 & 4910 & 4473 & 9765 & 14706 \\
\hline $\begin{array}{l}\text { Stavropol } \\
\text { Region }\end{array}$ & 430969 & 8425 & 177176 & 65085 & 122775 \\
\hline
\end{tabular}

The industrial structure in NCFR and Stavropol Region is graphically shown in Fig. 5, where a high growth of manufacturing industries is obviously overseen $(69 \%$ and $71 \%$, accordingly).

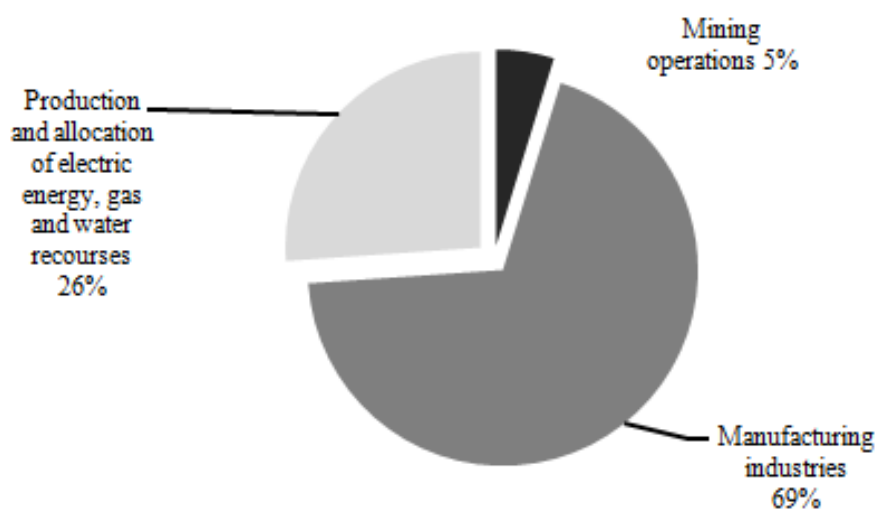




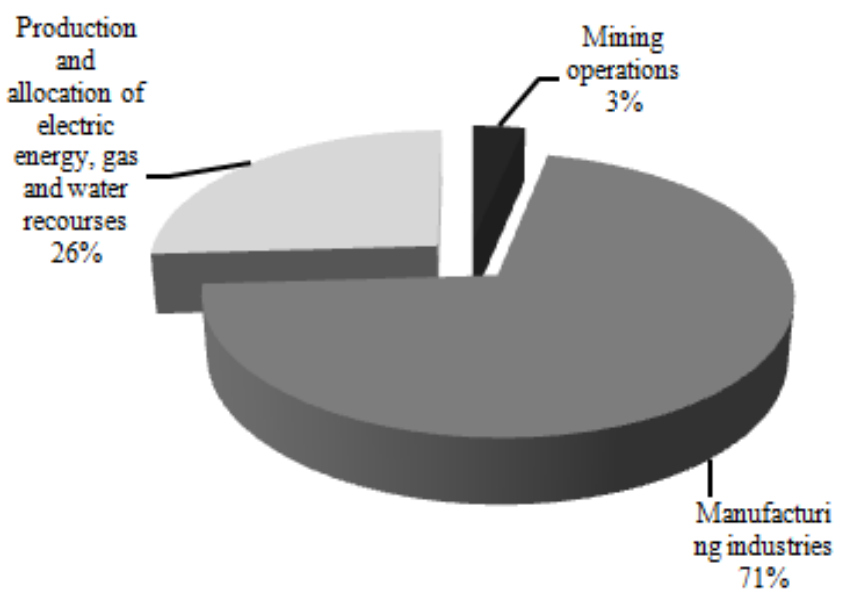

Fig. 5. The industrial structure in NCFR (first figure) and Stavropol Region (second figure) [1].

The largest share of dispatched products takes up manufacturing industries $(71 \%)$ in the industrial structure of Stavropol Region. This structure is provided in Fig. 6.

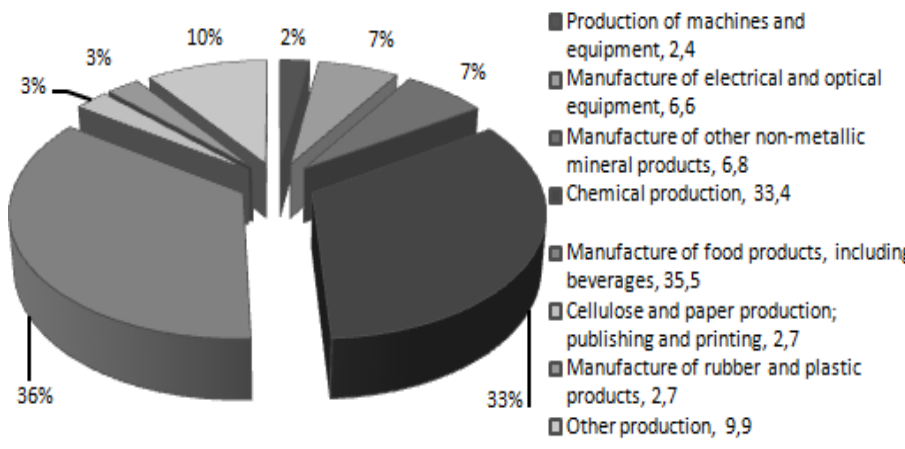

Fig. 6. Structure of separate Economical Industries in manufacturing sector, Stavropol Region.

The largest specific weight of manufacturing industries comprises the food production and chemical industries which create nearly $70 \%$ of volume private goods and services.

It is required to notice that this proportion does not change mostly within the long period, and the large enterprises chemical and food production is also stipulated.

Industrial enterprises are unevenly allocated within the territory of Region and mainly concentrate in western and southern parts of the country. (Fig. 7).

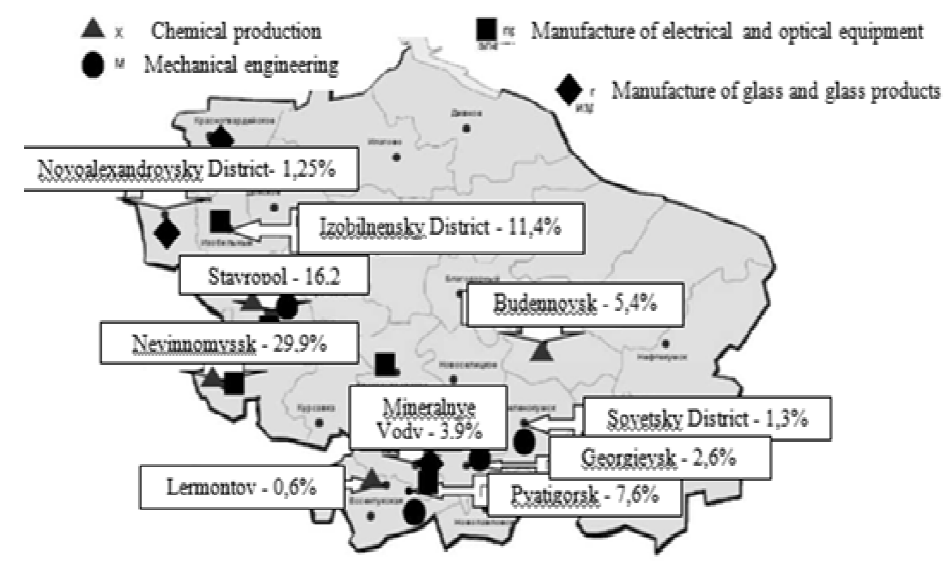

Fig. 7. Zoning of industry sectors and municipalities share of Stavropol Region GRP. [3]

In accordance with statistics, there are five advanced municipalities in which the leading industrial sectors within the territory are concentrated and form the major share of its GRP: Nevinomyssk-30 \%; Stavropol-16\%; Izobilnensky district-11\%; Pyatigorsk- 8\%; Budennovsk- $5 \%$.

The main industry sectors of the Region are chemical and food sectors. More than 130 organizations of the chemical industry are in the Region and OJSC «Arnest», OJSC «NevinnomiskAzot», PC «Stavropolen» and PC «AmetistSouth» are the largest of them. They are budgeting forming organizations.

The main produced products are mineral fertilizers, polyethylene, plastic, lacquers and paints, nitric and acetic acid, anhydrous ammonia, cosmetics, deodorants, detergents, protective serum and vaccines. It is necessary to notice that there is a lack of large processing plants of vegetable and meat products in Stavropol Region in spite of a sufficiently high share of agricultural production.

The largest processing plants include Stavropol canning factory, Novoalexandrovsk, Svetlograd and Georgievsk meat processing factories, Ipatovo poultry processing plant.

A distinctive feature of this sector is technological backwardness and shortage of investments for financing its accelerated development. This sector is extremely socially significant for the Region.

The organizations of medium and small businesses make up the base. In food industry of Stavropol Region, one can observe weak competitive positions and intensive introduction of goods from neighboring regions of the country and foreign enterprises. $80 \%$ of food industry is imported from other parts of the Region that negatively affects the competitiveness of local enterprises and, taking into account the state support program implementation of companies, is simultaneously considered as agro with potential.

The solution of infrastructure problems (forming of modern storage and processing systems of vegetables and meat products) and the technological development issues, according to the requirements of distribution networks, significantly increase the competitiveness of local producers. 
Generally, the industry has the great potential for creating new companies for agricultural products processing with the formation of the technological chain from field to processing process and then to a store, as well as gaining the larger share of regional market and export of products outside the region.

The sector has a weak investment attractiveness, but it is privileged for the growth of regional market development. It has own raw material and labor recourses. The specific weight of enterprises with innovation technologies makes about $6 \%$ [7].

The sector of chemical industry is visible updating, including production of vehicles, equipment and other industries including furniture. As for other enterprises, the decline of extent of wear of basic funds happened unevenly and insignificantly that continues to affect activity results and competitiveness of the organizations.

Analyzing the investment system of fixed assets of organizations that belong to the sphere of manufacturing, there are three leading industries: production of food products, chemical, other nonmetallic mineral products which are more than $90 \%$ of the total investment for the last years (Table 2).

TABLE II. FIXE DAS SETS INVESTMENT STRUCTURE AND MANUFACTURING INDUSTRIES IN STAVROPOL REGION (\%)

\begin{tabular}{|l|l|l|l|}
\hline Indicators & $\mathbf{2 0 0 5}$ & $\mathbf{2 0 1 0}$ & $\mathbf{2 0 1 4}$ \\
\hline Manufacturing industries including: & 100 & 100 & 100 \\
\hline $\begin{array}{l}\text { Food products production including } \\
\text { beverages }\end{array}$ & 27.3 & 36.3 & 19.7 \\
\hline Chemical industry & 48.6 & 26.1 & 64.3 \\
\hline $\begin{array}{l}\text { Production of other nonmetallic mineral } \\
\text { products }\end{array}$ & 8.6 & 29.4 & 3.5 \\
\hline $\begin{array}{l}\text { Production of electric equipment, } \\
\text { electron and optical equipment }\end{array}$ & 8.7 & 3.1 & 3.7 \\
\hline Others & 6.8 & 5.1 & 8.8 \\
\hline
\end{tabular}

It is necessary to notice that in 2010, there was a considerable increase of the share of funds which were allocated to the financing of food industry projects (from $27 \%$ in 2005 up to $36 \%$ in 2010) and production of other nonmetallic goods (from $9 \%$ in 2005 up to $29 \%$ in 2010). But specific weight of investment to the chemical industry projects is contrary reduced by almost half (from 56\% in 2006 up to $26 \%$ in 2010).

However, the share of investment to chemical industry was again dominated in $2014(64,3 \%)$. The share of financing projects within the investment of other sectors has not significantly changed for the analyzing period.

In the manufacturing industry, the situation in financing of expenditures on technological innovation has developed, where $91 \%$ of total expenses is spent on the chemical industry.

It provides the necessity for improving the industrial policy in order to develop multi-processing complex, which is a major factor in the development of investment in innovations.
As the chemical production has a leading position for balanced economy development in the region, it is required to establish interdependent organizations around the sector enterprises and form the cluster of innovation national economy sector of the region [7].

\section{PROPOSALS FOR SOLVING THE PROBLEM}

Economic essence of necessary for country modernization is in transformation from the commodity model of economic to innovation development meeting all interest and needs of population.

This issue is widely discussed in a special environment especially in relation to the requirements of improving regional economic policy, which can ensure the innovation development.

Although the «commodity» model of the economy of the country is criticized, its market development is not governed by the clear defined industrial policy aimed at strengthening the knowledge-intensive industries, and the predominant share of investment goes into the commodity sector.

The innovation economic presents as a sector of hightechnology industry with high specific weight of value added. At the same time, economic indicators and definition of the innovation sector are diluted, the direction of the sector development often coincides with the idea of the development of manufacturing industries.

According to statistical data, the share of value added in the mining operations sector after 2003 exceeded the corresponding indicators in the manufacturing sector more than twice.

By the way, more than half of the gross value added is created in the manufacturing industries sector. It was presented as a larger aggregate, that is, manufacturing industries as a whole but not high-technology industry, and the ratio is unfavorable for processing.

This statement is indirectly confirmed by the data of profitability of output of separate kinds of goods. The profitability level of coal mining, ore, ferrous and non-ferrous metals, as well as oil and gas production, several times higher than the profitability of the manufacturing industry including the high-technology industry sector [3].

The rate of growth of labor productivity is unfavorable for manufacturing industry, which in 2005-2008 due to high prices on raw materials exceeded the rate of productivity growth in the mining sector, but in 2009-2010 productivity declined and continues to decline nowadays although at much slower pace.

At the present stage, considering the economic development, one may identify a number of challenges hampering the development of many manufacturing industries Fig. 8): low human resource capacity, high wear and technological backwardness, low investment attractiveness, an insufficient level of innovation development, lack of research and development etc. [3]. 


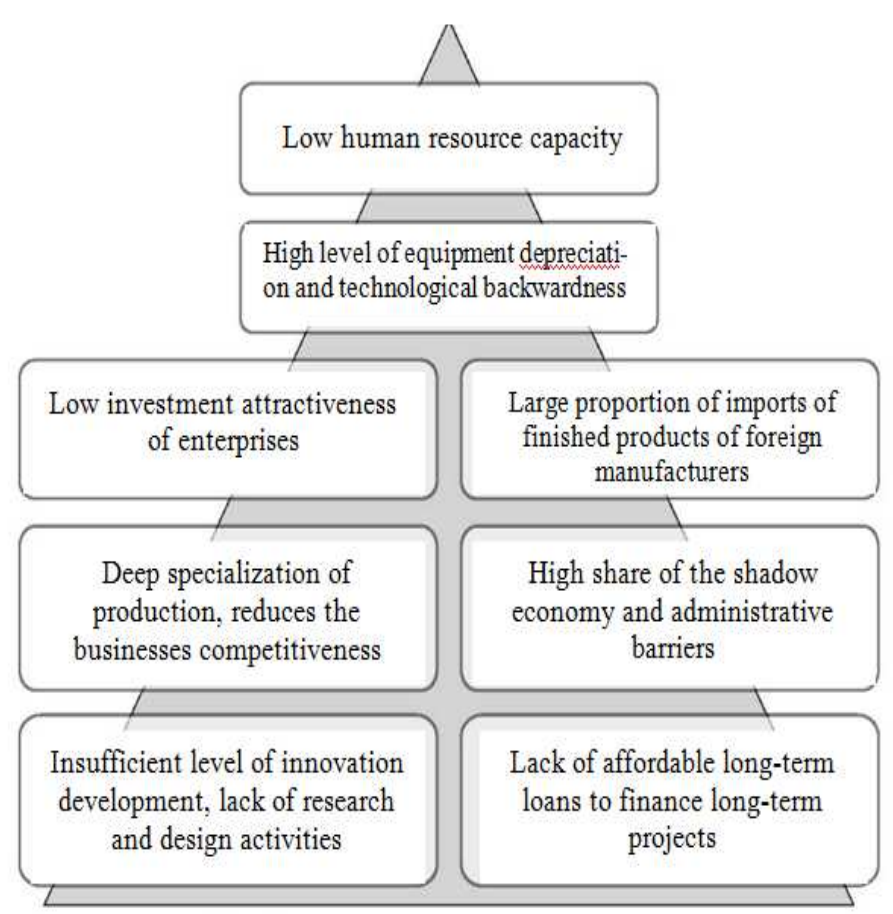

Fig. 8. Challenges hampering the development of manufacturing industry [3].

Thus, the research of dynamics of the production volume (works, services) of industrial enterprises in Stavropol Region indicates to the industry-wide reserves of economic growth for the long prospect using capacity of the created organizational and technological base.

The dynamics of development might be better within the manufacturing industry sectors, which are priority for the country and are presented as significant innovation potential including: chemical and food industry, glass production and its items, output of electric, electron and optical equipment and others.

In this regard, it is required to establish the integrated structures including one of the leading manufacturing industries as a main section («core») which development is ensured by the available resources in the region (labor, raw material, logistical and financial etc.).

In the case of their absence in the region, it is required to attract the additional recourses from other regions.
The special attention should be paid to industrial, technical and technological development of manufacturing industries, as well as the effective and complete use of raw material and labor resources in the region.

\section{References}

[1] Regions of Russia. Socioeconomic indicators. 2014. Online recourse. Website: http://www.gks.ru/

[2] Socioeconomic situation of Russia, 2014: Statistics col, M.: Rosstat, 2015.

[3] V.P. Kirpanev, P.N. Timoshenko, Industrial policy of manufacturing sectors: development and financing: monograph, Stavropol: Serviseschool, 148 p., 2014.

[4] N.N. Volkova, T.V. Sakhno, Industrial clusters, M.:Asmi, 2005, 272 p.

[5] G. S. Merzlikina, A. M. Varfolomeyeva, Process management of enterprise structure, Innovations and business as basis of modernization of regional economy, To Vestnikagt, M.: Economy, No. 2, pp. 199-203, 2010 .

[6] K. Omahe, The Invisible Continent. Four Strategic Imperatives of the New Economy, N.Y., 2000.

[7] V.N. Parahina, O.A. Boris, T.L. Bezrukova, I.I. Shanin, State support for creation and development of sociallyoriented innovative enterprises, Asian Social Science, Vol. 10, № 23, pp. 215-222, 2014.

[8] V.M. Vasiltsova, S.A. Dyatlov, V.S. Vasiltsov, T.L. Bezrukova, B.A. Bezrukov, Methodology of Management Innovation Hypercompetition, Asian Social Science, Vol. 11, No. 20, pp. 165-170, 2015.

[9] M. Solodovnikov, Competitive advantage: How to reach a good result and to provide its stability. The lane with English, M.: Alpina Business of Axle boxes, 2005, $607 \mathrm{p}$.

[10] V. V. Repin, V. G. Eliferov, Process approach to management. Modeling of business processes, M.: RIA "Standards and Quality", 408 p.

[11] K. Rogoff, On why not a global currency. HarvardUniversity, 2001.

[12] A. D. Smith, Nationalism and modernism: A crit. survey of recent theories nations and nationalism, New York: Routledge, 1998, $188 \mathrm{p}$.

[13] Fernando de Melo, V.V. Maslennikov, E.V. Popova, T.L. Bezrukova, I.V. Kyksova (). Quantitative Analysis in Economics Based on Wavelet Transform: a new approach, Asian Social Science, Vol. 11, No. 20, pp. 66-74, 2015.

[14] C. Chase-Dunn, Globalization: A World-Systems Perspective, Journal of World-Systems Research, vol. 5, Number 2, Spring, 1999.

[15] A.N. Ayupov, G. S. Zhumatayeva, Influence of globalization processes on economic and social situation of the countries of the Central Asian region: Collection of scientific works, Bishkek: Izd-VOKRSU, 2006, 149 p. 